\title{
Effect of high-intensity interval training on the skeletal muscle of spontaneously hypertensive rats
}

\author{
Paulo Henrique Aleixo ${ }^{1}$ (D), Robson Chacon Castoldi ${ }^{1}$, Francilene Lima Agostinho De Souza ${ }^{2}$, \\ Thaoan Bruno Mariano ${ }^{2}$, Guilherme Akio Tamura Ozaki ${ }^{3}$, Thiago Alves Garcia ${ }^{3}$, \\ Lucas Silva Santos ${ }^{4}$, Francis Lopes Pacagnelli ${ }^{2}$, Regina Celi Trindade Camargo ${ }^{1}$, \\ José Carlos Silva Camargo Filho ${ }^{1}$ \\ ${ }^{1}$ Universidade Estadual Paulista, "Júlio de Mesquita Filho", Departamento de Fisioterapia, \\ Presidente Prudente, SP, Brasil. ${ }^{2}$ Universidade do Oeste Paulista, Departamento de Fisioterapia, \\ Presidente Prudente, SP, Brazil. ${ }^{3}$ Universidade Estadual de Campinas, Departamento de \\ Ortopedia e Traumatologia, Campinas, SP, Brasil. ${ }^{4}$ Universidade do Oeste Paulista, \\ Departamento de Educação Física, Presidente Prudente, SP, Brasil.
}

Associate editor: Katia de Angelis, Departamento de Fisiologia, Universidade Federal de São Paulo, São Paulo, SP, Brasil.

\begin{abstract}
Aim: This study aimed to evaluate the effect of High-Intensity Interval Training (HIIT) on the skeletal muscle of Spontaneously Hypertensive Rats (SHR). Method: In total, 20 male rats, SHR, 12 months old, were used, distributed into 2 groups: Control Group (C) and Training Group (HIIT). The training lasted approximately 50 minutes/day, 5 days/week, for 8 weeks. Systolic blood pressure (BP) was measured at the beginning and end of the study. Analysis: The medial gastrocnemius muscle was used to measure the smallest fiber diameter, after which the Shapiro-Wilk normality test was performed, followed by the Mann Whitney test to compare the medians and interquartile intervals (IQI) of the muscle fibers and Student t-test for performance. For analysis of BP, Analysis of Variance - ANOVA was used, followed by Tukey's post-test. All procedures adopted a significance value of $5 \%(p<0.05)$. Results: The median values for the variable "smallest diameter" of muscle fibers were 29.48 (IQI: 9.96) $\mu \mathrm{m}$ in the C group and 33.45 (IQI: 9.44) $\mu \mathrm{m}$ in the HIIT group $(\mathrm{p}<0.05)$. Also, the performance was increased in the trained animal group and blood pressure values decreased significantly at the end of the experiment $(\mathrm{p}<0.05)$. Conclusion: The HIIT intensity promoted an increase in the median values of the muscle fibers and performance. Finally, a significant decrease was observed in blood pressure variation values.
\end{abstract}

Keywords: high-intensity interval training, arterial hypertension, spontaneously hypertensive rats, skeletal muscle.

\section{Introduction}

Blood pressure (BP) is a worldwide problem and care related to its control and treatment has been discussed by various health agencies. Systolic arterial hypertension $(\mathrm{SAH})$ is among the most relevant diseases in the population and is directly related to a high mortality rate ${ }^{1,2}$.

In the period from 1990 - 2013, SAH was responsible for the second-highest number of deaths in the world, totaling 10.4 million cases $^{3}$. Several factors contribute to the development of SAH. Among these, we can mention heredity, sex, ethnicity, age, diet, low physical fitness, and sedentary behavior ${ }^{4}$.

This disease can be related to several factors, such as stiffening of the arteries, caused by the accumulation of atheromatous plaque on the walls, left ventricular hypertrophy, and altered heart rate ${ }^{5,6}$. Scientific evidence has consistently shown that physical activity is recommended as a way of preventing, treating, and controlling $\mathrm{SAH}^{7}$.

Although conventional methods, such as drugs, are used to treat $\mathrm{SAH}$, physical exercise acts as an adjuvant in the control of blood pressure, generating adaptations to the stress caused by the exercises and improving peripheral circulation $^{8,9}$.

Physical training (PT) could be a non-pharmacological therapy in the treatment and prevention of SAH since it generates a series of physiological adaptations in the cardiorespiratory system ${ }^{10}$. Among these adaptations, blood vessel dilation increased myocardial contraction force, and, consequently, ejection volume can be highlighted. In addition, in skeletal muscle, PT can result in a higher number of mitochondria, as well as increased contraction strength and protein synthesis ${ }^{11}$. 
Hypertrophied muscle increases its function with greater efficiency. In this case, the calf musculature has a fundamental role in the regulation of blood pressure, as it acts in the prevention of vascular diseases in the lower limbs (LL) $)^{12,13}$.

In addition, the conjunction formed by the Gastrocnemius and Soleus muscles forms the Triceps Surae. The contraction of this musculature exerts pressure on the deep vessels of the cardiovascular system, pumping venous blood from the extremities of the lower limbs to the heart $^{14,15}$.

Among the different forms of exercise, the endurance modality is commonly prescribed for the treatment of $\mathrm{SAH}^{1,9}$. However, some studies have shown that highintensity interval training (HIIT) can promote physiological alterations that are similar or better than those caused by low and medium-intensity exercise ${ }^{16,17}$.

HIIT is a form of training with high intensity and short duration stimuli. These stimuli are interspersed with pauses that can be active or passive ${ }^{18}$. The concern regarding this method, however, is in relation to which populations can perform this modality since training should be prescribed with greater caution to people with heart disease or in an at-risk group, such as hypertensives and older adults. In this sense, physiological parameters should be established according to the needs of the individual $^{19}$.

As HIIT is an intense form of exercise, one option to test its use is in studies with animal models. Spontaneously hypertensive rats (SHR) genetically develop SAH from 4 to 20 weeks of age, due to several physiological factors of the species, such as increased BP and cardiac remodeling, factors that do not occur with Kyoto animals $^{20,21}$.

The advantage of studies with the use of animals is that they enable high control of variables and the possibility of using invasive methods as a form of analysis. In addition, the results obtained can be extrapolated to human beings, thus preserving the integrity of the human being $^{11,22}$.

When prescribing HIIT, several methods are adopted to establish safe parameters in relation to the control or decrease in BP. This study can corroborate with the literature, relating arterial hypertension with HIIT and its effects on the skeletal muscles of hypertensive patients. Thus, the current study aimed to evaluate the effects of HIIT on the skeletal muscle of spontaneously hypertensive rats (SHR).

\section{Method}

Sample

Twenty male rats, SHR, were used, 12 months of age, with a mean weight of 550 grams. The animals were subdivided into two groups: Control Group (C) [n = 10] and Training with HIIT Group (HIIT) [n=10].

The animals remained in groups of 5 animals per box (polyethylene), with a controlled ambient temperature $\left(22+2{ }^{\circ} \mathrm{C}\right)$ and brightness (12-hour light/dark cycle and inverted cycle), with free access to water and feed (laboratory rat feed). The study was developed according to the ethical standards and principles of animal experimentation after approval by the Ethics Committee on the use of animals (CEUA - 4115).

\section{Stress and performance test}

The animals were initially submitted to adaptation to training, consisting of running on a treadmill at a speed of 6 meters per minute $(\mathrm{m} / \mathrm{min}$.), lasting 5 minutes, for 5 days. After the adaptation period, the animals were submitted to the maximum speed test to assess the physical capacity of each animal.

The test started at a speed of $6 \mathrm{~m} / \mathrm{min}$ with increments of $3 \mathrm{~m} / \mathrm{min}$ every 3 minutes until the exhaustion of each animal ${ }^{23,24}$. The animals were considered exhausted when they were unable to run even after stimulation. The speed obtained in the test determined the training prescription. This protocol was performed at the beginning of the study and after 4 weeks of training ${ }^{24}$ and the performance was obtained through the distance determination.

\section{HIIT Training}

The training protocol was performed on 2 treadmills adapted for rodents (model TK 1, IMBRAMED), for approximately 50 minutes/day (40-60 $\mathrm{min}$ ), 5 days/week, for 8 weeks. The training was performed in an inverted cycle, adapted from Haram et al. ${ }^{25}$ and Moreira et al. ${ }^{26}$, and took place from $14 \mathrm{~h}$ to $14 \mathrm{~h} 50 \mathrm{~min}$.

Each training session consisted of three phases: warm-up, HIIT, and cool-down. The warm-up included 5 minutes at $60 \%$ of the exhaustion speed. The HIIT was started at $95 \%$ of the speed reached in the exhaustion test $(21 \mathrm{~m} / \mathrm{min}$ ) for 4 minutes, interspersed with $65 \%$ of the exhaustion speed for 3 minutes. The training was repeated five times during the first and second weeks.

In the third and fourth weeks, the HIIT was performed at the same speed as the first week $(95 \%$ of exhaustion speed), however, repeated 6 and 7 times per session, consecutively. After the end of the fourth week of training, a new stress test was performed to reevaluate the exhaustion speed and the training load was adjusted.

In the fifth and sixth weeks, the HIIT was carried out with an adapted protocol and the animals performed training at a speed of $23 \mathrm{~m} / \mathrm{min}$ for 4 minutes, interspersed by $12 \mathrm{~m} / \mathrm{min}$ for three minutes, repeated 7 times.

In the seventh week there was an increase in the speed of HIIT corresponding to $15 \%$ and in the eighth week to $18 \%$ of the maximum speed, performed for 4 
minutes, interspersed by $65 \%$ of the maximum speed for three minutes, repeated 7 times $^{25,26}$. The details of the HIIT and the experimental design are described below ${ }^{27}$ (Figure 1).

\section{Systolic blood pressure}

The tail-cuff plethysmography method was used to obtain blood pressure control. The systolic blood pressure was verified using the tail-cuff (Narcobio system ${ }^{\circledR}$, model709-0610, International Biomedical, Inc, USA), before and after the training period. One week before the beginning of the experiment the animals were adapted to the use of this device. The difference in blood pressure values was obtained through the mean BP and the delta value $\Delta$ : (final value-initial value).

\section{Skeletal muscle}

Forty-eight hours after the end of the experiment, the animals were euthanized with an overdose of anesthetics (ketamine hydrochloride and xylazine hydrochloride), administered intraperitoneally ${ }^{28}$. Next, the Medial Gastrocnemius muscle was extracted and immersed in $10 \%$ formaldehyde solution ${ }^{18,28}$.

After this procedure, the skeletal muscle was processed, embedded in paraffin, and histological sections of $5 \mu \mathrm{m}$ thickness were made. The slices were produced transversely, in the ventral portion of the muscle, in a rotating microtome, and stained with hematoxylin-eosin $(\mathrm{HE})^{22,28,29}$.

\section{Optical microscopy}

The slices were observed and photomicrographed using a Nikon® microscope, model 50i. An Infinityl camera was used to analyze the images. The markings for determining the smallest diameter of the muscle fiber passing through the center were made using the software (AuxioVisionRel 4.8 - Carl Zeiss ${ }^{\circledR}$ and NIS-Elements D3.0 - SP7 - Nikon $)^{30}$.

In total, 10 slices of $5 \mu \mathrm{m}$ were produced and 120 muscle fibers were measured per animal, according to the protocol established by Dubowitz ${ }^{30,31}$. After obtention of the images of the muscle fibers, the smallest diameter was measured, as shown in Figure $2^{30,31}$.

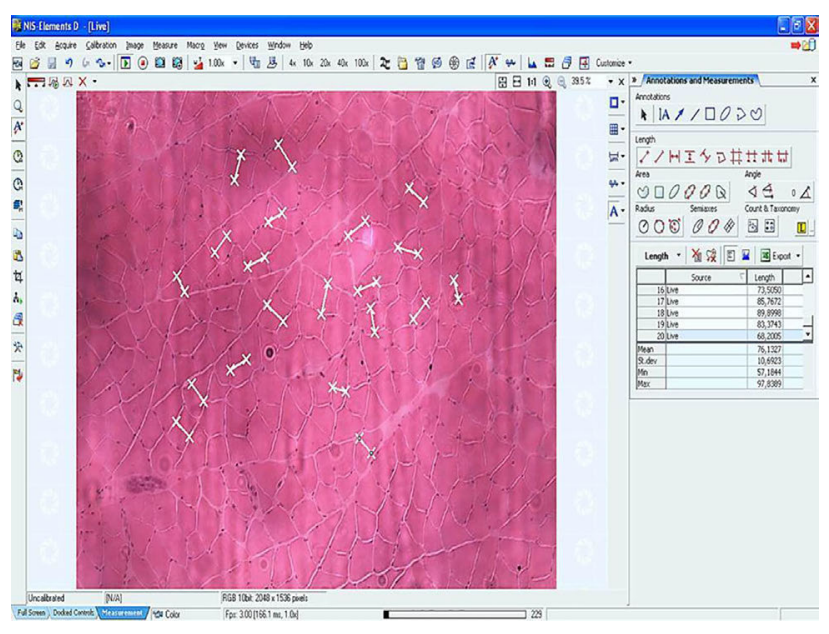

Figure 2 - NIS-Elements D3.0 - SP7 - Nikon ${ }^{\circledR}$ Software and measurement of the smallest fiber diameter.

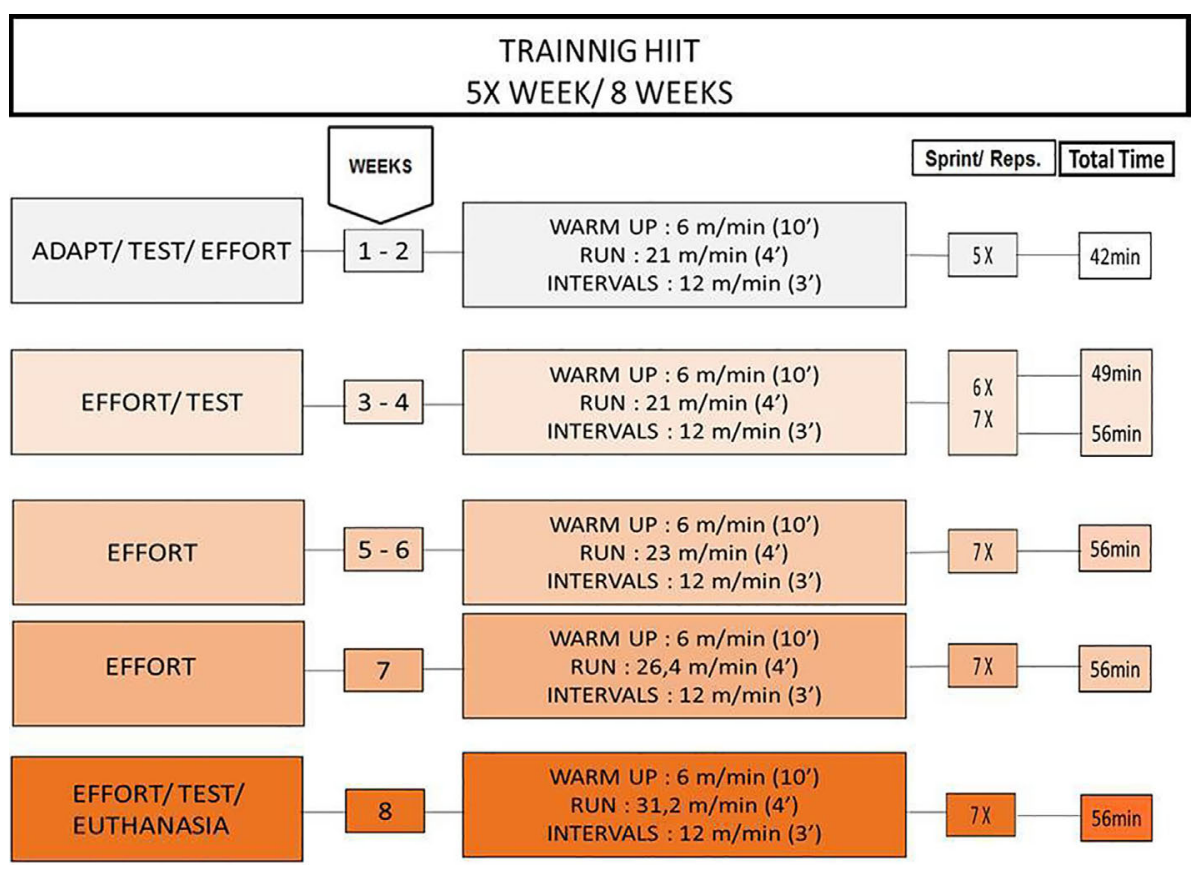

Figure 1 - Training Protocol used in the present study. 


\section{Statistical analysis}

The Shapiro-Wilk test was performed to verify the normality of the data, followed by the Mann-Whitney test for the comparison between medians of muscle fibers and the Student t-test for performance. For analysis of BP, Analysis of Variance - ANOVA was used, followed by Tukey's post-test. All procedures adopted a significance value of $5 \%(p<0.05)$.

\section{Results}

With hematoxylin-eosin (HE) staining, it was possible to analyze different morphologies, such as the muscle cells (dark arrows) and cell nuclei (light arrows) between the different groups of animals (Figure 3 ).

A significant increase was observed in the median values for the variable "smallest diameter" in the HIIT group, 33.45 (IQI: 9.44) $\mu \mathrm{m}$, compared with the C group, 29.48 (IQI: 9.96) $\mu \mathrm{m}$ (Figure 4). Also, it was observed an increase in performance in the HIIT group $(\mathrm{p}<0.05)$ (Figure 5).

Finally, blood pressure values presented a significant decrease between groups, when comparing the beginning and end of the experiment $(\mathrm{p}<0.05)$ (Table 1).

\section{Discussion}

The findings of the current study showed that highintensity interval training (HIIT) promoted a significant increase in the median values of the smallest diameter variable in the muscle fibers of the Medial Gastrocnemius of spontaneously hypertensive rats (SHR) $(\mathrm{p}<0.05)$. In addition, a significant decrease in systolic blood pressure was observed $(\mathrm{p}<0.05)$.

Adaptations in the calf muscles have important effects on venous return and, consequently, on blood pres-
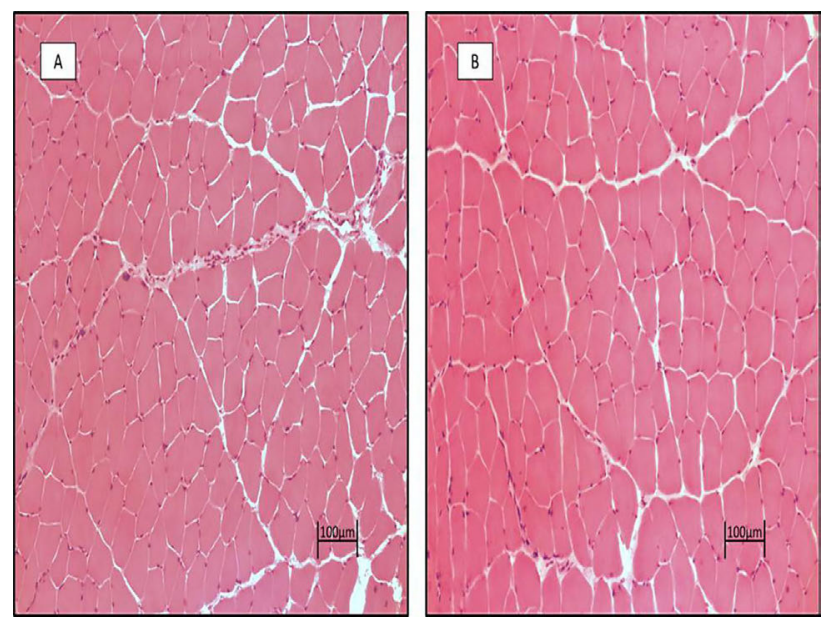

Figure 3 - Muscle fibers from bcontrol and HIIT training after eight weeks in rats. (A): Control Group; (B): HIIT training Group. Hematoxylin-eosin (HE) staining.

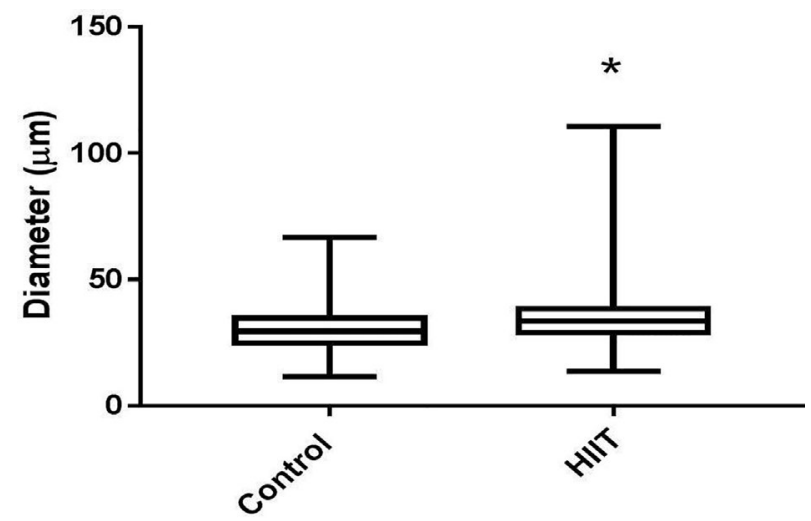

Animals Group

Figure 4 - Comparison between medians between control and HIIT training rats after eight weeks. $(*)$ Statistical difference presented by the Mann Whitney test with a significance value of $5 \%(\mathrm{p}<0.05)$. Control Group (SHR rats, $\mathrm{n}=10$ ). HIIT training Group (SHR rats, $\mathrm{n}=10$ ). Values exposed in medians and interquartile intervals (IQI).

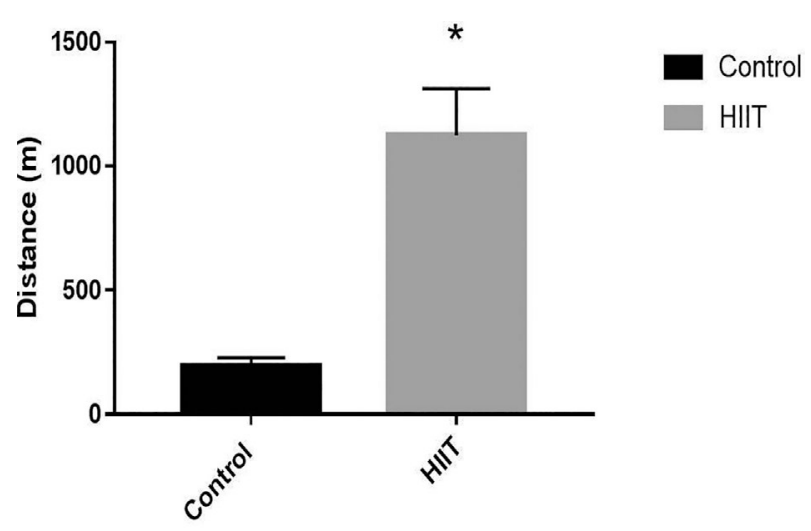

\section{Animals Group}

Figure 5 - Comparison of performance between control and HIIT training rats after eight weeks. $\left.{ }^{*}\right)$ Statistical difference presented by the Student t-test with an error of $5 \%$ (p-value $\mathrm{p}<0.05$ ). Control Group (SHR rats, $\mathrm{n}=10$ ). HIIT training Group (SHR rats, $\mathrm{n}=10$ ).

Table 1 - Systolic blood pressure results.

\begin{tabular}{lcccccc}
\hline Groups & $\begin{array}{c}\text { Blood pres- } \\
\text { sure }\end{array}$ & $\begin{array}{c}\text { Before } \\
(\mathbf{m m H g})\end{array}$ & $\begin{array}{c}\text { After } \\
(\mathbf{m m H g})\end{array}$ & $\boldsymbol{p}$ & $\Delta$ & $\boldsymbol{p}$ \\
\hline Control & Mean & 202.12 & 223.85 & & 21.73 & \\
& $\begin{array}{c}\text { Standard } \\
\text { Deviation }\end{array}$ & 25.43 & 33.29 & 0.187 & & 0.012 \\
\multirow{2}{*}{ HIIT } & Mean & 210.80 & 200.35 & & -10.45 & \\
& Standard & 18.95 & 21.27 & & & \\
& Deviation & & & & &
\end{tabular}

Comparison between means in different groups of animals after eight weeks. Analysis of Variance test - ANOVA with Tukey post-test. HIIT: High-Intensity Interval Training. Variation in systolic blood pressure $\Delta$ : final value - initial value. Control Group (SHR rats, $n=10$ ). HIIT training Group (SHR rats, $\mathrm{n}=10$ ). 
sure $^{32,33}$. These muscle gains are important concerning arterial hypertension, as muscle hypertrophy promotes greater vascularization in the tissues, due to the increase in the number of blood vessels (angiogenesis), a fact that allows the better exchange of gas and energy substrates such as fat ${ }^{34}$. This muscle is directly connected to the calf muscle pump which, when contracted, compresses the deep tibial veins and ejects blood back to the heart. This mechanism aids in venous return and, thus, in BP control $^{35}$.

This mechanism was observed by Lima et al. ${ }^{36}$ in a case study that evaluated the hemodynamic pump musculature (Triceps Sural) of a patient diagnosed 21 years previously with chronic venous insufficiency and concluded that strengthening this region can improve the quality of life and autonomy of individuals with this disease.

It is worth mentioning that in the present study, muscle hypertrophy, an increase in performance, and a significant decrease in blood pressure were found among the groups of trained animals. This finding corroborates the study by Borges ${ }^{37}$ who analyzed the systolic and diastolic blood pressure and heart rate of rats.

However, it should be noted that the Borges proto$\mathrm{col}^{37}$ consisted of a single training session, and the findings demonstrated that the animals which performed an HIIT protocol presented reduced BP values when compared to the continuous training group. In this sense, as it takes less time to perform and results in similar benefits, the use of HIIT could be advantageous.

Ferreira $^{38}$ used an HIIT protocol in hypertensive animals and found that this training model demonstrated efficiency in reducing blood pressure. However, although the same training protocol was used, pressure values were compared with the addition of Wistar Kyoto animals, which differs from the present study ${ }^{20,39}$.

In humans, several studies suggest that HIIT can improve blood pressure. In a review performed by Kessler ${ }^{40}$ positive results were observed with regard to a reduction in blood pressure after 12 weeks of training.

Nemoto $^{41}$ analyzed interval training in walking and noted an increase of $17 \%$ in isometric knee extension and flexion. In addition, the peak aerobic capacity for cycling increased by $8 \%$ and aerobic capacity for walking by $9 \%$. Furthermore, a decrease in blood pressure at rest was observed.

These findings direct attention to the fact that HIIT includes a high intensity of exercise, and is applied individually, which did not occur in the current study. Our findings may support the literature when investigating the effects of an HIIT protocol on skeletal muscle and blood pressure in SHR. However, some limitations should be highlighted, such as the ergometer (treadmill) used, and that the animals performed the training at the mean level of the stress test and, thus, some animals performed different percentages of effort. Future studies that consider other training methods, as well as different forms of ergometers, may collaborate with the present study.

\section{Conclusion}

It was observed that HIIT promoted an increase in median values for the variable of the smallest diameter in the muscle fibers of SHR animals. Also, the performance was increased in the trained animal group.

In addition, a significant reduction was observed in blood pressure between the initial and final moments in the HIIT group. These findings suggest that it is possible to use this form of training in the clinical environment for patients with SAH, both for increasing muscle mass and reducing $\mathrm{BP}$.

\section{References}

1. Cornelissen VA, Fagard RH, Coeckelberghs E, Vanhees L. Impact of resistance training on blood pressure and other cardiovascular risk factors. Hypertens. 2011;58(5):950-8.

2. Piccinato $\mathrm{CE}$, Cherri J, Moriya T. Hipertensão e doença arterial periférica. Rev Bras Hipertens, 2001;8(3):306-15.

3. Jesus NSD, Nogueira ADR, Pachu CO, Luiz RR, Oliveira GMMD. Adesão ao tratamento e Controle da Pressão Arterial após participação no ReHOT. Arq Bras Cardiol., 2016;107(5):437-45.

4. Matavelli IS, Del Judice EL, Matavelli R, Hunger MS, Martelli A. Hipertensão Arterial Sistêmica e a Prática Regular de Exercícios Físicos como Forma de Controle: Revisão de Literatura. Rev Bras Ciênc Saúde. 2015;18(4):359-66.

5. Ferreira Filho C, Meneghini A, Riera ARP, Neto AS, Teixeira GK, Ferreira C. Benefícios do exercício físico na hipertensão arterial sistêmica. Arq Med do ABC. 2007;32(2):827.

6. Cano-montoya J, Álvarez C, Martínez C, Salas A, Sade F, Ramírez-Campillo R. Recuperación cardiovascular durante ejercicio intermitente en pacientes con hipertensión y diabetes tipo 2 altamente adherentes. Rev Med de Chile. 2016;144(9):1150-8.

7. Pescatello LS, MacDonald HV, Lamberti L, Johnson BT. Exercise for hypertension: a prescription update integrating existing recommendations with emerging research. Curr Hypertens Rep. 2015;17: 87.

8. Krotkiewski M, Lithell H, Shono N, Wysocki M, Holm G. High blood pressure and muscle morphology/metabolismcausal relationship or only associated factors? Clin Physiol (Oxford, England), 1998;18(3):203-13.

9. Holloway TM, Bloemberg D, Da Silva ML, Simpson JA, Quadrilatero J, Spriet LL. High-intensity interval and endurance training have opposing effects on markers of heart failure and cardiac remodeling in hypertensive rats. PloS One, 2015;10(3): e0121138.

10. McMillan EM, Graham DA, Rush JW, Quadrilatero J. Decreased DNA fragmentation and apoptotic signaling in soleus muscle of hypertensive rats following 6 weeks of treadmill training. J Appl Physiol. 2012;113(7):1048-57.

11. Fiorenza M, Gunnarsson TP, Ehlers TS, BangsboJ. Highintensity exercise training ameliorates aberrant expression 
of markers of mitochondrial turnover but not oxidative damage in skeletal muscle of men with essential hypertension. Acta Physiologica, 2019;225(3):e13208.

12. Baptista MT, do Nascimento FXM, Nardes LK, da Matta TT, de Oliveira LF. Influência de posições do joelho no torque e atividade mioelétrica do tríceps sural na flexão plantar isométrica máxima. Rev Bras Educ Fís Esporte. 2014;28 (2):197-202.

13. Rodrigues FP. O conhecimento da bomba muscular da panturrilha em praticantes de musculação. Rev Científica UMC, 2018;3:1-3.

14. Campos CCC, Albuquerque PCD,Braga IJDS. Avaliação do volume de fluxo venoso da bomba sural por ultra-sonografia Doppler durante cinesioterapia ativa e passiva: um estudo piloto. J Vasc Bras, 2008;7(4):325-32.

15. Araki CT, Back TL, Padberg FT, Thompson PN, Jamil Z, Lee BC, et al. The significance of calf muscle pump function in venous ulceration. J Vasc Surg, 1994;20(6):872-9.

16. Coswig V, Corrêa L, Sobrinho A, Del Vecchio F. Exercício intermitente de alta intensidade como alternativa na reabilitação cardiovascular: uma metanálise. Rev Bras de Ativ Fís \& Saúde. 2015;20(4):340-51.

17. Bowen TS, Eisenkolb S, Drobner J, Fischer T, Werner S, Linke Aet al. High-intensity interval training prevents oxidant-mediated diaphragm muscle weakness in hypertensive mice. The FASEB J. 2017;31(1):60-71.

18. Gillen JB, Gibala MJ. Is high-intensity interval training a time-efficient exercise strategy to improve health and fitness? Appl Phys Nutr, Metabol. 2013;39(3):409-12.

19. De Jesus Siqueira GD, Maioni LL, Soares V, Lima WA. Efeito hipotensor subagudo de uma sessão de treinamento intervalado de alta intensidade (HIIT). Cinergis. 2017;18 (2):114-20.

20. Bloemberg D, McDonald E, Dulay D, QuadrilateroJ. Autophagy is altered in skeletal and cardiac muscle of spontaneously hypertensive rats. Acta Physiologica, 2014;210 (2):381-91.

21. Quadrilatero J, Rush JW. Increased DNA fragmentation and altered apoptotic protein levels in skeletal muscle of spontaneously hypertensive rats. J Appl Physiol. 2006;101 (4):1149-61.

22. Camargo Filho JCS, Vanderlei LCM, Camargo RCT, Francischeti FA, Belangero WD, Pai VD. Efeitos do esteroide anabólico nandrolona sobre o músculo sóleo de ratos submetidos a treinamento físico através de natação: estudo histológico, histoquímico e morfométrico. Rev Bras Med Esporte. 2006;2(5):218-22.

23. Rossoni LV, Oliveira RAF, Caffaro RR, Miana M, SanzRosa D, Koike MK, et al. Cardiac benefits of exercise training in aging spontaneously hypertensive rats. J hypertension. 2011;29(12):2349-58.

24. Pagan LU, Damatto RL, Cezar MDM, Lima ARR, Bonomo C, Campos DHS, et al. Long-term low-intensity physical exercise attenuates heart failure development in aging spontaneously hypertensive rats. Cell Physiol Biochem. 2015;36 (1):61-74.

25. Haram PM, Kemi OJ, Lee SJ, Bendheim MO, Al-Share QY, Waldum HL, et al. Aerobic interval training vs. continuous moderate exercise in the metabolic syndrome of rats arti- cially selected for low aerobic capacity. Cardiovasc Res. 2009;81:723-32.

26. Moreira JBN, Bechara LRG, Bozi LHM, Jannig PR, Monteiro AWA, Dourado PM, et al. High- versus moderateintensity aerobic exercise training effects on skeletal muscle of infarcted rats. J App Physiol. 2013;114:1029-41.

27. Wisloff U, Stoylen A, Loennechen JP, Morten O, Rognmo O, Haram PM, et al. Superior cardiovascular effect of aerobic interval training versus moderate continuous training in heart failure patients: a randomized study. Circulation. 2007;115:3086-94.

28. Koike TE, Watanabe AY, Kodama FY, Ozaki GAT, Castoldi RC, Garcia TA, et al. Physical exercise after immobilization of skeletal muscle of adult and aged rats. Rev Bras Med Esporte 2018;24(1):60-3.

29. Castoldi RC, Teixeira GR, Malheiro OCM, Camargo RCT, Belangero WD, Camargo Filho JCS. Effects of 14 weeks resistance training on muscle tissue in Wistar rats. Int. J. Morphol. 2015;33(2):446-451.

30. Dubowitz V, Brooke MH. Muscle biopsy: A modern approach, London, WB Saunders Company, Ltd. 1973.

31. Dal-Pai V. Histoenzimologia: teoria e prática. Instituto de Biociências - Unesp, Botucatu, 1995.

32. Bortolotto SK, Cellini M, Stephenson DG, Stephenson GM. $\mathrm{MHC}$ isoform composition and $\mathrm{Ca} 2+$-or $\mathrm{Sr} 2+$-activation properties of rat skeletal muscle fibers. AJP-Cell Physiol. 2000;279(5):C1564-17.

33. Quadrilatero J, Rush JW. Evidence for a pro-apoptotic phenotype in skeletal muscle of hypertensive rats. Biochem Biophys Res Commun. 2008;368(1):168-74.

34. Bucci M, Vinagre EC, Campos GER, Curi R, Pithon-Curi TC. Efeitos do treinamento concomitante hipertrofia e endurance no músculo esquelético. Rev Bras Ciên Mov. 2008;13(1):17-28.

35. Engelhorn CA, Beffa CV, Bochi G, Pullig RC, Picheth FS, Cunha SS. Avaliação por pletismografia a ar da função da bomba muscular da panturrilha conforme a idade. J Vasc Bras. 2020;2(1):13-6.

36. Lima RCM, Santiago L, Moura RMF, Filaretti FAZ, Souza CSA, Evangelista SSM, et al. Efeitos do fortalecimento muscular da panturrilha na hemodinâmica venosa e na qualidade de vida em um portador de insuficiência venosa crônica. J Vasc Bras. 2002;1(3):219-26.

37. Borges JP, Masson GS, Tibiriçá E, Lessa MA. Exercício Aeróbio Intervalado Induz Maior Redução na Sobrecarga Cardíaca na Recuperação em Ratos. Arq Bras Cardiol. 2014;102(1):47-53.

38. Ferreira NZ, De Souza FLA, Mariano TB, Carrara B, Collegio $\mathrm{G}$, Molinari AO, et al. Efeito hipotensor do exercício intervalado de alta intensidade em animais espontaneamente hipertensos. Colloq Vitae. 2017;9 (3).

39. Atrakchi AISAR, Gray SD, Carlsen RC. Development of soleus muscles in SHR: relationship of muscle deficits to rise in blood pressure. AJP-Cell Physiol. 1994;267(3): C827-35.

40. Kessler HS, Sisson SB, Short KR. The potential for highintensity interval training to reduce cardiometabolic disease risk. Sports Med. 2012;42(6):489-509. 
41. Nemoto K, Gen-no H, Masuki S, Okazaki K, Nose H. Effects of high-intensity interval walking training on physical fitness and blood pressure in middle-aged and older people. Mayo Clin Proc. 2007;82:803-11.

\section{Corresponding author}

Paulo Henrique Aleixo, Rua Roberto Simonsen 305, Presidente Prudente, SP, Brasil.

E-mail: Aleixo99@hotmail.com.
Manuscript received on March 24, 2020

Manuscript accepted on March 15, 2021

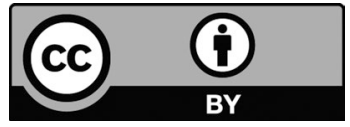

Motriz. The Journal of Physical Education. UNESP. Rio Claro, SP, Brazil - eISSN: 1980-6574 - under a license Creative Commons - Version 4.0 